\title{
Influence of eutectic addition on the electrical conductivity of $\mathrm{Li}_{2} \mathrm{O}: \mathbf{B}_{2} \mathrm{O}_{3}$ system
}

\author{
V K DESHPANDE and K SINGH \\ Department of Physics, Nagpur University, Nagpur 440010 , India \\ MS received 4 July 1986; revised 13 November 1986
}

\begin{abstract}
Addition of three eutectics, $\mathrm{Li}_{2} \mathrm{SO}_{4}: \mathrm{Li}_{2} \mathrm{CO}_{3}, 3 \mathrm{Li}_{2} \mathrm{O} \cdot \mathrm{Nb}_{2} \mathrm{O}_{5}: \mathrm{LiNbO}_{3}$ and $\mathrm{AgI}: \mathrm{Ag}_{2} \mathrm{SO}_{4}$ has been tried in the $\mathrm{Li}_{2} \mathrm{O}: \mathrm{B}_{2} \mathrm{O}_{3}$ glass system. The electrical conductivity increases with the addition of eutectic. The amount of lithium fraction and the melting point of the eutectic govern the conductivity.
\end{abstract}

Keywords. Eutectic; lithium fraction; electrical conductivity.

\section{Introduction}

In recent years, considerable research has been devoted to electrolytes based on $\mathrm{Li}$ ion conducting glasses suitable for solid state batteries. Non-crystalline solid electrolytes have definite advantages over their crystalline counterparts, like isotropic properties, ease of thin film formation, flexibility of size and shape (at satisfactory cost) etc. One of the important features of glass as a solid electrolyte is the possibility of continuous change of the composition over a wide range. A major characteristic of oxide glasses concerns the large variation in the conductivity with alkali oxide content. Recently, more complex glasses have been synthesized by dissolving salts in an oxide based glass (Smedley and Angell 1978; Levasseur et al 1979a).

A number of workers have reported fast ion conduction in lithium borate glasses (Otto 1966; Charls 1966; Levasseur et al 1979b; Bièfeld et al 1978; Audier et al 1976; Malugani and Robert 1979; Glass et al 1978). As reported by Singh and Rokade (1984), conventionally quenched $\mathrm{Li}_{2} \mathrm{O}: \mathrm{B}_{2} \mathrm{O}_{3}(40: 60 \mathrm{~m} \%)$ is the best homogeneous glass-forming composition with maximum conductivity. Tuller and Button (1985) have suggested that an enhancement in the conductivity of $\mathrm{Li}_{2} \mathrm{O}: \mathrm{B}_{2} \mathrm{O}_{3}$ system can be obtained by increasing the alkali ion concentration. According to Øye (1963) the mobility of $\mathrm{Li}$ ion increases in the presence of silver ions. Low melting point is one of the important criteria responsible for high ionic conductivity (Reau et al 1978). In a binary system, an eutectic is the lowest melting point composition.

By considering the above factors, an attempt has been made to study the influence on the electrical conductivity of $\mathrm{Li}_{2} \mathrm{O}: \mathrm{B}_{2} \mathrm{O}_{3}(40: 60)$ system by the addition of $\mathrm{Li}_{2} \mathrm{SO}_{4}: \mathrm{Li}_{2} \mathrm{CO}_{3}, 3 \mathrm{Li}_{2} \mathrm{O} \cdot \mathrm{Nb}_{2} \mathrm{O}_{5}: \mathrm{LiNbO}$ and $\mathrm{AgI}: \mathrm{Ag}_{2} \mathrm{SO}_{4}$ eutectics. It is expected that the presence of these eutectics in the glass system under study will provide an enhancement in the conductivity.

\section{Experimental details}

In the present work, the starting materials, $\mathrm{Li}_{2} \mathrm{SO}_{4}, \mathrm{Li}_{2} \mathrm{CO}_{3}, \mathrm{~B}_{2} \mathrm{O}_{3}, \mathrm{AgI}, \mathrm{Ag}_{2} \mathrm{SO}_{4}$ and $\mathrm{Nb}_{2} \mathrm{O}_{5}$ of $99.9 \%$ purity were used for the synthesis of the glasses. For preparing 
$\mathrm{Li}_{2} \mathrm{SO}_{4}: \mathrm{Li}_{2} \mathrm{CO}_{3}$ eutectic, about $10 \mathrm{~g}$ of raw material in eutectic ratio $(60: 40) \mathrm{m} \%$ was weighed to an accuracy of $0.0001 \mathrm{~g}$ and mixed under acetone. The mixture was then heated in an electric furnace. It was maintained at a temperature of $20 \mathrm{~K}$ above the melting point for $2 \mathrm{hr}$ to homogenize the melt. Then the melt was quenched in an aluminium mould at room temperature. This eutectic was then crushed to a fine powder and added in the host $\mathrm{Li}_{2} \mathrm{O}: \mathrm{B}_{2} \mathrm{O}_{3}$ system.

Similarly, other eutectics of $3 \mathrm{Li}_{2} \mathrm{O} \cdot \mathrm{Nb}_{2} \mathrm{O}_{5}: \mathrm{LiNbO}_{3}$ and $\mathrm{AgI}: \mathrm{Ag}_{2} \mathrm{SO}_{4}$ were prepared. Later, these eutectics were added in different concentrations to the lithium borate glass. In all these compositions, the ratio of $\mathrm{Li}_{2} \mathrm{O}: \mathrm{B}_{2} \mathrm{O}_{3}$ was maintained to be $40: 60 \mathrm{~m} \%$. After quenching the glasses in aluminium mould, they were immediately transferred to an annealing furnace maintained at $473 \mathrm{~K}$. After $4 \mathrm{hr}$ of annealing, the samples were subjected to furnace cooling.

The glasses thus obtained were polished flat. Silver paint was used to ensure the ohmic contact before loading the sample in the sample holder which has been described elsewhere (Deshpande and Singh 1982). The conductivity of these samples was measured at $1 \mathrm{kHz}$ as a function of temperature.

\section{Results and discussion}

Figure 1 shows the variation of $\log \sigma T$ vs $10^{3} / T$ tor $\mathrm{Li}_{2} \mathrm{O}: \mathrm{B}_{2} \mathrm{O}_{3}$ glass system with addition of three eutectics; $\mathrm{Li}_{2} \mathrm{SO}_{4}: \mathrm{Li}_{2} \mathrm{CO}_{3}, 3 \mathrm{Li}_{2} \mathrm{O} . \mathrm{Nb}_{2} \mathrm{O}_{5}: \mathrm{LiNbO}_{3}$ and $\mathrm{AgI}: \mathrm{Ag}_{2} \mathrm{SO}_{4}$. In general, the conductivity increases with increase in temperature. Typical conductivity values at two different temperatures, lithium fraction and the melting point of the dopant eutectic, are given in table 1 and it is evident that the addition of all the

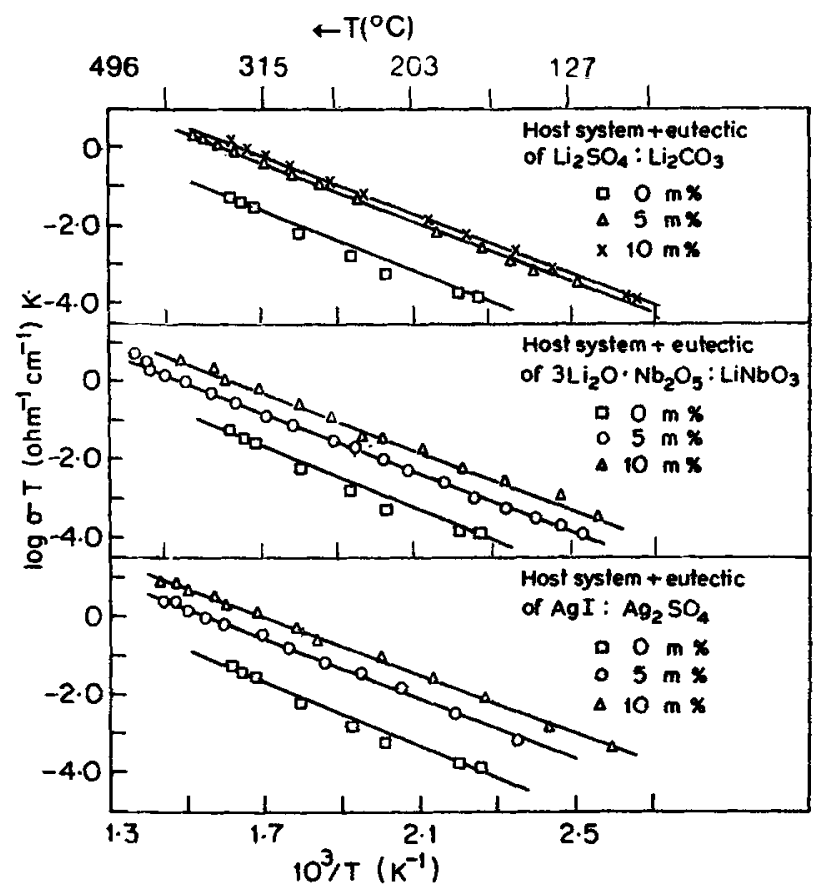

Figure 1. Variation of $\log \sigma T$ vs $10^{3} / T$ for $\mathrm{Li}_{2} \mathrm{O}: \mathrm{B}_{2} \mathrm{O}_{3}$ host system with the addition of three different eutectic. 
Table 1. Conductivity values at 623 and $523 \mathrm{~K}$, lithium fraction and melting point of the dopant eutectic.

\begin{tabular}{|c|c|c|c|c|}
\hline $\begin{array}{l}\mathrm{Li}_{2} \mathrm{O}: \mathrm{B}_{2} \mathrm{O}_{3}(40: 60) \\
+10 \mathrm{~m} \% \text { of eutectic }\end{array}$ & $\begin{array}{l}\sigma \text { in ohm } \\
623 \mathrm{~K}\end{array}$ & $\begin{array}{r}\mathrm{cm}^{-1} \text { at } \\
523 \mathrm{~K}\end{array}$ & ${ }^{*} f_{\mathbf{L A}}+$ & $\begin{array}{l}\text { Melting point } \\
\text { of the eutectic }\end{array}$ \\
\hline & $1.15 \times 10^{-4}$ & $5.70 \times 10^{-5}$ & 0.80 & \\
\hline $\mathrm{Li}_{2} \mathrm{SO}_{4}: \mathrm{Li}_{2} \mathrm{CO}_{3}$ & $2.02 \times 10^{-3}$ & $1.51 \times 10^{-4}$ & 0.92 & $\begin{array}{l}530^{\circ} \mathrm{C} \\
\text { (Amadori 1912) }\end{array}$ \\
\hline $3 \mathrm{Li}_{2} \mathrm{O} \cdot \mathrm{Nb}_{2} \mathrm{O}_{5}: \mathrm{LiNbO}_{3}$ & $1.60 \times 10^{-3}$ & $1.35 \times 10^{-4}$ & 0.84 & $\begin{array}{l}1160^{\circ} \mathrm{C} \\
\quad \text { (Reismen 1958) }\end{array}$ \\
\hline $\mathrm{AgI}: \mathrm{Ag}_{2} \mathrm{SO}_{4}$ & $4.03 \times 10^{-3}$ & $5.3 \times 10^{-4}$ & 0.72 & $\begin{array}{l}158^{\circ} \mathrm{C} \\
\quad \text { (Takahashi et al 1972) }\end{array}$ \\
\hline
\end{tabular}

${ }^{*} f_{\mathrm{Li}}+=\frac{{ }^{2 n} \mathrm{Li}_{2} \mathrm{O}+{ }^{2 n} \mathrm{Li}_{2} \mathrm{SO}_{4}+{ }^{2 n} \mathrm{Li}_{2} \mathrm{CO}_{3}}{{ }^{n} \mathrm{Li}_{2} \mathrm{O}+{ }^{n} \mathrm{~B}_{2} \mathrm{O}_{3}+{ }^{n} \mathrm{Li}_{2} \mathrm{SO}_{4}+{ }^{n} \mathrm{Li}_{2} \mathrm{CO}_{3}}$

where $n_{i}$ is the number of moles of constituent $i$ in the mixture.

three eutectics enhances the conductivity of the host system by more than an order of magnitude. The enhanced conductivity for higher.concentration of the first two eutectics is due to increased $\mathrm{Li}^{+}$fraction. Similar enhancement in the conductivity with increasing $\mathrm{Li}^{+}$fraction has been reported earlier (Deshpande et al 1985).

Among the three eutectic samples, the conductivity for $3 \mathrm{Li}_{2} \mathrm{O} \cdot \mathrm{Nb}_{2} \mathrm{O}_{5}: \mathrm{LiNbO}_{3}$ is minimum. This is because of its higher melting point and lower lithium fraction than that for $\mathrm{Li}_{2} \mathrm{SO}_{4}: \mathrm{Li}_{2} \mathrm{CO}_{3}$. The lithium fraction for $10 \mathrm{~m} \% \mathrm{Li}_{2} \mathrm{SO}_{4}: \mathrm{Li}_{2} \mathrm{CO}_{3}$ containing sample (0.92) is higher than that observed for $7 \mathrm{~m} \% \mathrm{Li}_{2} \mathrm{SO}_{4}$ containing $\mathrm{Li}_{2} \mathrm{O}: \mathrm{B}_{2} \mathrm{O}_{3}$ glass (0.88) (Deshpande et al 1985). Also the conductivity in this case is higher than what was reported earlier for $7 \mathrm{~m} \% \mathrm{Li}_{2} \mathrm{SO}_{4}$ added sample. Thus, the melting point of the eutectic and the lithium fraction governs the conductivity for eutectic of lithium salts.

For $10 \mathrm{~m} \% \mathrm{AgI}: \mathrm{Ag}_{2} \mathrm{SO}_{4}$ eutectic, maximum conductivity is observed. This is because of the lowest melting point of this sample over all the others studied in the present investigation. This sample was a homogeneous glass without any crystallization in it suggesting that, upto $10 \mathrm{~m} \%, \mathrm{AgI}: \mathrm{Ag}_{2} \mathrm{SO}_{4}$ gets adjusted in the amorphous matrix of the host system. The $\mathrm{SO}_{4}$, being tetrahedra might extend the $\mathrm{BO}_{3} / \mathrm{BO}_{4}$ glass network. Due to the larger size of the iodine, it expands the lattice which enhances the mobility of the mobile ion. In this case, silver ions might also contribute to the conduction. However, due to non-availability of the experimental facilities, it was not possible to separate out the contribution of silver and lithium ions. The study of $\operatorname{AgX}(\mathrm{X}=\mathrm{I}, \mathrm{Br})$ containing borate glasses suggests that $\mathrm{AgI}$ containing glasses give more conductivity (Minami et al 1982). According to Minami (1983), those $\mathrm{Ag}$ ions surrounded by halide ions in the glass contribute to the conduction. In $\mathrm{B}_{2} \mathrm{O}_{3}$ containing glasses, $\mathrm{Ag}$ ions interacting with $\mathrm{BO}_{4}$ groups also contribute to the conduction as well as the $\mathrm{Ag}$ ions surrounded by halide ions.

\section{Conclusion}

From the present investigation it can be concluded that, lower the melting point of the eutectic, higher is the conductivity of the system. The maximum value of conductivity, $\sigma \simeq 4.03 \times 10^{-3} \mathrm{ohm}^{-1} \mathrm{~cm}^{-1}$ at $623 \mathrm{~K}$ obtained for sample with $10 \mathrm{~m} \% \mathrm{AgI}: \mathrm{Ag}_{2} \mathrm{SO}_{4}$ eutectic can be used for technical applications. 


\section{References}

Amadori M 1912 Atti Relea Acad. Lincel Sex II 2168

Audier M, Ravaine D and Souquet J C 1976 C R Acad. Sci. C282 499

Biefeld R M, Johnson R T and Baughman R J 1978 J. Electrochem. Soc. 125179

Charls R J $1966 \mathrm{~J}$. Am. Ceram. Soc. 4955

Deshpande V K and Singh K 1982 Solid State Iorics 618

Deshpande V K, Rokade S and Singh K 1985 Proc. Sixth Riso Int. Symp. on Transport-structure Relations in fast ion and Mixed Conductor, (eds) F W Poulsen. $N$ Hessel Andersen, K Clausen, S Skaarup and O Toft Sorensen (Denmark: RISO National Laboratory) 227

Glass A M, Nassau K and Negran T J 1978 J. Appl. Phys. $\$ 4808$

Levasseur A, Kbala M, Brethous J C, Reau J M and Hagenmuller P 1979a Solid State Commun. 32839 Levasseur A, Brethous J C, Reau J M and Hagenmuller P 1979b Mater. Res. Bull. 14921

Malugani J P and Robert G 1979 Mater. Res. Bull. 141075

Minami T, Ikeda Y and Tanaka M 1982 J. Non-Cryst. Solids 52159

Minami T 1983 J. Non-Cryst. Solids 5615

Otto K 1966 Phys. Chem. Glasses 729

Oye H A 1963 Thesis, Trondheim, Norway

Reau J M, Portier J, Levasseur A, Villenuve and Pouchard M 1978 Mater. Res. Bull. 131415

Reismen A and Holtzberg F 1958 J. Am. Chem. Soc. 186503

Singh K and Deshpande V K 1982 Proc. DAE Symp. on Interactions at electrode Electrolyte Interfaces Indian Inst. Technol., Madras, p 167

Singh K and Rokade S 1984 J. Power Sources 13151

Smedley S I and Angell C A 1978 Solid State Commun. 2721

Takahashi T, Nomura E and Yamamoto O 1972 J. Appl. Electrochem. 251

Tuller H L and Button D P 1985 Proc. Sixth Rise Int. Symp. on Transport-structure Relation in fast ion and Mixed conductors, Denmark, 119 